\title{
Vloga mentorja v e-izobraževanju
}

Ema Perme

Doba, Maribor
I

zobraževanje odraslih in še posebej zaposlenih se kaže v vsej svoji razsežnosti. Delodajalci se vse bolj zavedajo, da zaposleni z ustreznim znanjem in pravilnim opravljanjem različnih delovnih postopkov prinašajo dobiček, ki je tudi končni cilj vsake produkcije. Prav iz teh razlogov je nujno vlaganje $\mathrm{v}$ razvoj strokovnih pristopov v izobraževanje zaposlenih, to pa pomeni tudi tako imenovano v e-izobraževanje, saj pridobljena izobrazba ni več nekaj trajnega, temveč zastareva spričo tehnoloških ter tehničnih inovacij, hitrih sprememb v načinu dela in socialne dinamike. ${ }^{1}$ Poleg tega nikoli doslej čas ni bil tako pomemben in nikoli doslej ni učna tehnologija ponujala toliko možnosti za racionalno izrabo časa, pri opravljanju najrazličnejših vrst dela in tudi pri izvajanju najrazličnejših vrst izobraževanja.

Sposobnost za učenje, glede na obseg vsebin, se bo zelo povečala, prav tako pa se bo povečalo tudi število področij, na katerih si bomo kar sočasno pridobivali znanje. Pri eizobraževanju napovedujejo več osebne pozornosti, več interakcije $\mathrm{z}$ mentorjem in več

Tako kot je spoznanje o vseživljenjskem učenju pred desetletji povzročilo revolucionaren pogled na potrebo po učenju in znanju v odcasli dobi, prav tako $z$ internetom tičenje in izobraževanje dobiva popolnoma novo podobo. Strokovnjaki trdijo, da je internet ena največjih tehnološih pridobitev po tisku prve knjige pred 500 leti in da ne bo spremenil le načina učenja, ampak ga bo po napovedih celo izboljšal. povratnih informacij o napredku v znanju. E-izobraževanje omogoča aktivno sodelovanje vsem udeležencem izobraževanja. Sproža revolucijo in napredek $v$ izobraževanju odraslih na vseh področjih, pri nadaljnjem poklicnem in strokovnem izobraževanju, usposabljanjem za delo in pri izvajanju seminarjev ter konferenc. Prodrlo bo tudi na vse univerze in $\mathrm{v}$ celoti spremenilo način izobraževanja.

Strokovnjaki in svetovalci za različna področja dela in delovnih procesov ga bodo vodili kar od doma. Mentorja tradicionalne oblike izobraževanja, ki se srečuje z udeleženci ob istem času in $\mathrm{v}$ istem prostoru, bo zamenjal tako imenovani e-mentor, ki za uspešno opravljanje svojega dela potrebuje dodatno znanje.

Spremenilo se bo tudi razmerje tistih, ki bodo lahko vodili e-izobraževanje. Bill Draves primerja vpliv izobraževanja »on-line $\ll^{2}$ na družbo kot celoto s vplivom traktorja na predelavo hrane. Pred stoletjem je bila hrana izjemno draga in na voljo $\mathrm{v}$ omejenih količinah, danes pa je razmeroma poceni in imamo jo v velikih količinah. Podobno vlogo bo imel internet na izobraževalnem področju. Več posameznikov se bo lahko učilo več, z nižjimi stroški, na voljo bodo različne vsebine in področja, posamezna med njimi pa bo obvladalo le nekaj strokovnjakov. Ti bodo usposobljeni tudi za e-mentorstvo, saj bo komunikacija »on-line« najustreznejši način posredovanja znanja in izkušenj, poleg tega pa bodo opravljali tudi svoje strokovno delo. Zgodilo se bo nekaj, o čemer je družba v preteklosti lahko le sanjala. ${ }^{3}$ 


\section{VLOGA MENTORJA V IZOBRAŽEVANJU ODRASLIH}

Prav zaradi značilnosti učenja in možnosti pridobivanja znanja je tradicionalna podoba učitelja, ki ima znanje in ga posreduje, že preživela. Namesto njega imamo mentorja, ki ima vlogo moderatorja izobraževalnega procesa na vseh ravneh izobraževanja odraslih. Mentor je vodnik na poti do znanja skozi učne vire. Njegova naloga je, da spodbuja kritično razmišljanje o problemih in udeležencem omogoča prosto pot iskanja rešitev, postavlja dodatna vprašanja in omogoča kritično presojanje lastnega napredovanja $\mathrm{v}$ znanju. Dober mentor ima prakMentor je moderator izobraževalnega procesa. tične izkušnje s področja, ki je predmet izobraževanja, pozna različne vire in teoretična izhodišča, izbira ustrezne postopke ter metode dela, s katerimi doseže visoko stopnjo aktivnosti udeležencev in jih spodbuja k sodelovanju. Pri tem ne smemo prezreti njegove vloge spodbujevalca, ki skrbi za vzdrževanje ustrezne ravni želje ter hotenja po nadaljnjem izobraževanju in za uspešno učno klimo.

Ker se mentor v izobraževanju srečuje z odraslimi, je pomembno, da pozna njihove odzive v izobraževanju. Pri tem upošteva njihovo bogastvo izkušenj. Vloga mentorja je tako vezana na spopadanje $s$ »preteklostjo« udeležencev, z bogatimi delovnimi izkušnjami, predhodnim znanjem, jasno predstavo o tem, kaj želijo v izobraževanju pridobiti, pa tudi s strahovi pred neuspehom in negativnimi občutki. Za mentorja je pomembno, da poskrbi za dobro komunikacijo $\mathrm{z}$ udeleženci in med njimi samimi. V izobraževanje vstopajo posamezniki $\mathrm{z}$ različnimi stopnjami motivacije in vsak po svoje razumejo lasten napredek pridobivanja znanja. Zato veljata načeli, da je odgovornost do učenja domena vsakega posameznika in da je mentorjeva vloga poma- gati vsakemu udeležencu, da v izobraževanju aktivno sodeluje in napreduje.

Te značilnosti je pomembno upoštevati tudi pri e-izobraževanju.

\section{MENTOR V E-IZOBRAŽEVANJU}

Mentor v e-izobraževanju, v tuji literaturi je uveljavljen tudi pojem e-moderator, ${ }^{4}$ se po nekaterih značilnostih razlikuje od tradicionalnega mentorja, ki si nekako še vedno lahko »privošči« tradicionalno vlogo. Komunikacijo na podlagi retorike in neverbalne komunikacije, ki jo s pridom uporablja tradicionalni mentor, je pri e-mentorju zamenjala pisna komunikacija, ki jo mora e-mentor uspešno in dobro obvladati. Prav tako zna ravnati s programsko opremo, ki je podpora e-izobraževanju, in obvlada kulturo komuniciranja po internetu. Kultura komuniciranja po internetu ali tako imenovana »net-etika« (angl. netiquette) ima svoja pravila. Uporabnike navaja na upoštevanje nekaterih neformalnih načel, ki naj bi jih pri komuniciranju po internetu $\mathrm{v}$ prihodnosti vsi spoštovali. ${ }^{5}$ Orodja, ki e-mentorju pomagajo pri e-komunikaciji z udeleženci, so e-pošta in učno okolje na internetu. Udeleženci in mentor $\mathrm{v}$ učno okolje na internetu vstopajo z uporabniškim imenom in geslom, ponuja pa jim vsebine za samostojno predelavo ( $\mathrm{z}$ dodanimi primeri, povezavami do drugih virov znanja, zvokom, sliko), možnost razprave in kritičnega reševanja problemov z udeležbo vseh udeležencev e-izobraževanja $v$ tako imenovani klepetalnici ter možnosti predelave vsebin s samopreverjanjem napredovanja $\mathrm{v}$ znanju. E-mentor spremlja sodelovanje udeležencev in kritično presoja napredovanje pri pridobivanju znanja. $\mathrm{Z}$ dodatnimi vprašanji in predlogi po potrebi poseže v skupinsko delo, da se skupina uspešno približuje izobraževalnemu cilju.

Različni avtorji vlogo mentorja v e-izobraževanju opredeljujejo po funkciji, možnostih, ki 
Zane L. Berge meni, da moramo za uspešno e-izobraževanje zagotoviti:

1. Pedagoške možnosti. Udeležencem je na voljo učna vsebina, e-mentor pa jih spodbuja $k$ predelavi in razpravi, tako da osvojijo koncepte in drugo znanje, s posebnimi dodatki misli, virov, postavljanjem ustreznih vprašanj za razmišljanje ipd. Pripravlja navodila za uporabo delovnih metod in tehnik za ustrezno predelavo vsebin. Daje povratne informacije o napredovanju v znanju.

2. Motivacijo. E-mentor oblikuje prijateljsko klimo, ki je pogoj za uspešno moderiranje skupine. Skrbi za pristne odnose, razvoj skupinske dinamike in povezanost skupine in za to, da udeleženci med seboj sodelujejo in so v pomoč drug drugemu. E-mentor si mora pri udele- žencih pridobiti zaupanje. To doseže z nataněnostjo, izpolnjevanjem obljubljenega, posredovanjem jasnih navodil za delo in ustreznimi odgovori na njihova vprašanja.

3. Organizacijske možnosti. E-mentor določa časovne roke za opravljanje posameznih nalog, pravila dela $v$ skupini, organizira delo $\mathrm{v}$ manjših skupinah ali parih ter z ustreznim načrtovanjem predelave vsebin poskrbi, da vsi pravočasno opravijo zastavljene naloge.

4. Tehniěne možnosti. E-mentor daje udeležencem navodila za uporabo tehnike oziroma učnega okolja, ki ga za izobraževanje uporabljajo. Pri tem mora obvladati funkeije uporabe programskega orodja, ki se uporablja pri izobraževanju, in ga znati tudi razložiti. ${ }^{6}$ jih treba zagotoviti v e-izobraževanju, in nalogah, ki jih mentor opravlja.

Rohfeld in Hiemstra (C. Shepherd, 2000) poudarjata, da je mentorjeva najpomembnejša naloga zagotavljanje učinkovitega učenja in prevzemanje odgovornosti za vzdrževanje razprave, pripravo posebnih prispevkov, usmerjanje udeležencev med razpravo in vsebino ter ohranjanje skupinske harmonije.

\section{NAŠE IZKUŠNJIE}

Na Dobi, višji strokovni šoli v Mariboru, smo oblikovali program e-izobraževanja na daljavo za pridobitev poklica poslovni sekretar, za njegovo izvajanje pa smo usposobili tudi mentorje, ki smo jih imenovali kar mentorji »on-line«. Pri usposabljanju so se preizkusili $\mathrm{v}$ dejanskih razmerah, $\mathrm{s}$ predelavo vsebin $\mathrm{s}$ temo dela mentorja »on-line«.

$\mathrm{Na}$ koncu smo opravili analizo usposabljanja. Zaradi drugačne komunikacije in izvajanja procesa usposabljanja $\mathrm{z}$ uporabo tehnik in metod »on-line « za kratko ponazoritev njihovega doživljanja e-usposabljanja dodajam kratke povzetke odgovorov na nekatera vprašanja.

Doseganje ciljev programa so v celoti potrdili z najvišjo oceno, dodali so, da so bili cilji na začetku dobro predstavljeni, pri samem usposabljanju pa so prepoznavali doseganje vmesnih ciljev in tudi splošnega, $\mathrm{k}$ čemur jih je vodilo uspešno zastavljeno usposabljanje in delo mentorice. V skupini so dobro napredovali glede na vsebine in jih včasih celo presegli, saj v ciljih nismo zapisali, da bodo pridobili tudi zanimiv krog znancev in celo prijateljev. Usposabljanje kot celoto so v vsi ocenili $\mathrm{z}$ najvišjo oceno in dodali, da je bilo zelo dobro organizirano in vodeno s strani mentorice. Usposabljanje je bilo celovito in premišljeno pripravljeno, prav tako razporeditev nalog in delo, ki je bilo izredno motivacijsko zastavljeno. Vprašali smo jih tudi, kako so doživeli komunikacijo. Poudarili so, da je učno okolje na internetu zelo koristen študijski pripomoček, saj je ves čas vse evidentirano in shranjeno. Možnost vključevanja s časovnim zamikom in prispevki, ki jih posameznik dodaja sam, daje tovrstnemu usposabljanju veliko vrednost. Sodelovanje z drugimi udeleženci pri reševanju različnih nalog pa je okrepilo delo v skupini.

Poudarki naših e-mentorjev, ki smo jih usposabljali na Dobi, potrjujejo tuje izkušnje in kažejo, da je mogoče z e-izobraževanjem doseči visoko stopnjo interakcije med udele- 
ženci in mentorjem, pri čemer ni bojazni, da bi tehnika slabo vplivala na odnose, ampak nam je ta v veliko pomoč pri izvajanju izobraževanja. Učenje se kaže v vsej svoji veličini, saj gre za upoštevanje zahtev posameznika pri razporejanju časa in kraja ter možnost uporabe različnih aktivnih metod dela ter tehnik učenja.

\section{NAMESTO SKLEPNIH MISLI}

E-mentorji so nova generacija v izobraževanju, ki bo poskrbela, da bo informacijska računalniška tehnologija dobrodošlo sredstvo za oblikovanje koristnih, zanimivih in učin-

\section{E-izobraževanje izboljšuje računalniško pismenost.}

kovitih možnosti za izobraževanje. S posodabljanjem izobraževanja zaposlenih bo tudi Slovenija pripravljena na primerjavo in merjenje s svetovnim trgom ter svetovno informacijsko družbo. Gre za nov izziv, ki ga ponujajo sodobni pristopi $\mathrm{k}$ učenju in izobraževanju. Ustrezno usposobljeni strokovnjaki, ki bodo lahko delovali kot e-mentorji, bodo pomenili nov korak v razvoju dodatnega usposabljanja zaposlenih.

Pri uporabi informacijske računalniške tehnologije v izobraževalne namene navajajo številne prednosti z vidika racionalizacije stroškov, saj se zmanjšujejo stroški porabe sredstev za potovanja in odsotnost $\mathrm{z}$ dela med izobraževanjem zaposlenih. Hkrati pa izraba delovnih sredstev, kot so računalniki, v izobraževalne namene dodatno upravičuje naložbo, pri zaposlenih pa posredno izboljšuje tudi računalniško pismenost. Vložek v tako imenovano izobraževanje »on-line « dolgoročno vsekakor vpliva na zmanjševanje stroškov pri vlaganju v nadaljnje izobraževanje zaposlenih. Taka oprema pa je tudi dobra podlaga za usposobitev strokovnjakov v organizacijah za opravljanje e-mentorstva.

\section{LITERATURA}

Berge, Z. L. (1995): The Role of the On-line Instructor/Facilitator, http://www.emoderators.com/moderators/teach_online.html

Draves, W. A. (1997): How to Teach Adults, LERN, Manhattan, Kansas, ZDA.

Draves, W. A. (1997): Teaching On-line, LERN, Wisconsin, ZDA.

Draves, W. A. (2001): Learning on the net, LERN, Wisconsin, ZDA.

Jelenc - Krašovec, S. (1996): ABC izobraževanja odraslih, Andragoški center RS, Ljubljana.

A. Mohorčič, V., Ivančič, A. (1996): Potrebe po izobraževanju odraslih, Andragoški center RS, Ljubljana.

Salmon, G. (2000): E-moderating: The Key to Teaching and Learning On-line, Kogan Page Limited, London, Velika Britanija.

Shea, V. (1994): Netiquette, Albion Books, San Francisco, ZDA, http://www.albion.com/netiquette/

Sheffield College (2000); LeTTOL - Learning to Teach On-line, delovno gradivo on-line-usposabljanja mentorjev.

Šega, L. (1997): Veliki poslovni moderni slovar, CZ, Ljubljana.

\section{DRUGI VIRI}

http://jan.ucc.nau.edu/ mpc3/moderate/teach_online.html

http://www.fastrak-consulting.co.uk/tactix/Features/human/human.htm

http://distlearn.man.ac.uk/distance/emoderatingWorkshop/emoderating-15-05-01.htm

http://teachers.net/gazette/MAY01/bowman.html

http://www.lern.org

11 A. Mohorčič, V., Ivančič, A. (1996): Potrebe po izobraževanju odraslih, Andragoški center RS, Ljubljana.

2 On-line: (prid.) povezan z (glavnim) računalnikom; Šega, L. (1997): Veliki poslovni moderni slovar, CZ, Ljubljana.

${ }^{3}$ Draves, W. A. (2001): Learning on the net, LERN, Wisconsin, ZDA.

4 Salmon, G. (2000): E-moderating: The Key to Teaching and Learning Online, Kogan Page Limited, London, Velika Britanija.

${ }^{5}$ Shea, V. (1994): Netiquette, Albion Books, San Francisco, ZDA, http://www.albion.com/netiquettel

${ }^{6}$ Berge, Z. L. (1995): The Role of the On-line Instructor/Facilitator, http://www.emoderators.com/moderators/teach_online.html 